\title{
Germination and initial development of Simira gardneriana M.R. Barbosa \& Peixoto (Rubiaceae) seedlings under different temperatures and salinity levels
}

\section{Germinação e desenvolvimento inicial de plântulas de Simira gardneriana M.R. Barbosa \& Peixoto (Rubiaceae) em diferentes temperaturas e níveis de salinidade}

\author{
Fabrícia Nascimento de Oliveira ${ }^{1}$; Thiago Hadady da Silva Castro²; Salvador \\ Barros Torres ${ }^{3}$; Narjara Walessa Nogueira ${ }^{3}$; Rômulo Magno Oliveira de Freitas ${ }^{4 *}$
}

\begin{abstract}
Simira gardneriana M.R. Barbosa \& Peixoto (Rubiaceae) is a species exclusive to the Caatinga biome. It is used as forage, firewood, and in the construction of fence posts. Species from this biome are constantly subjected to abiotic stresses, including salt and thermal stress. Thus, we evaluated the effect of irrigation water salinity on the germination and initial development of $S$. gardneriana seedlings at different temperatures. The experiment used seeds with an initial moisture content of about $12.32 \%$, arranged in a factorial scheme with eight levels of salinity, obtained by the addition of sodium chloride $(\mathrm{NaCl})$, diluted in distilled water at concentrations of 0.0 (control), 1.5, 2.5, 3.5, 4.5, 5.5, 6.5, and 7.5 $\mathrm{dS} \mathrm{m}{ }^{-1}$, and the four temperatures $25,30,35$, and $20-30^{\circ} \mathrm{C}$, in four replicates of 25 seeds each. Salinity and temperature effects were evaluated based on germination, germination speed index, seedling shoot length, root length, shoot dry matter, root dry matter, and total dry matter. Increasing water salinity levels interfered with all variables analyzed in the germination of $S$. gardneriana seeds, especially at a temperature of $35^{\circ} \mathrm{C}$. At temperatures of 25 and $30^{\circ} \mathrm{C}$, seed germination and initial development were less affected by salinity. Simira gardneriana seeds are sensitive to salinity caused by the increase in $\mathrm{NaCl}$ from $1.5 \mathrm{dS} \mathrm{m}^{-1}$, which indicates a low tolerance of this species to saline environments. Our results show that the negative effect on the germination and initial development of $S$. gardneriana seedlings can be explained by the increase in salt levels and temperature, reducing their capacity to absorb water and nutrients, which indicates sensitivity responses of this species to salinity and thermal stress.
\end{abstract}

Key words: Caatinga Biome. Electrical conductivity. Salt stress. Thermal stress. Vigor.

\section{Resumo}

Simira gardneriana M.R. Barbosa \& Peixoto (Rubiaceae), é uma espécie exclusiva do bioma Caatinga, utilizada como forrageira, e a madeira usada para lenha e estacas na construção de cercas. Espécies desse bioma são submetidas, constantemente, a estresses abióticos, entre eles o salino e o térmico.

1 Prof ${ }^{a}$, Departamento de Engenharia e Ciências Ambientais, Universidade Federal Rural do Semi-Árido, UFERSA, Mossoró, RN, Brasil. E-mail: fabricia@ufersa.edu.br

2 Eng $^{\circ}$ Agr $^{\circ}$, UFERSA, Mossoró, RN, Brasil. E-mail: thiago.castro.93@hotmail.com

3 Profs., Departamento de Ciências Agrárias, UFERSA, Mossoró, RN, Brasil.E-mail: sbtorres@ufersa.edu.br; narjara.nogueira@ ufersa,edu.br

4 Prof., Instituto Federal de Educação, Ciência e Tecnologia do Ceará, IFCE, Campus Crato, Crato, CE, Brasil. E-mail: romulomagno_23@hotmail.com

* Author for correspondence 
Dessa forma, objetivou-se avaliar o efeito da salinidade da água de irrigação na germinação e no desenvolvimento inicial de plântulas de $S$. gardneriana em diferentes temperaturas. Nesse estudo foram utilizadas sementes com teor de água inicial em torno de $12,32 \%$ às quais foram arranjadas em esquema fatorial com oito níveis de salinidades, obtidos a partir da adição de cloreto de sódio $(\mathrm{NaCl})$ e diluídos em água destilada nas concentrações de 0,0 (testemunha); 1,$5 ; 2,5 ; 3,5 ; 4,5 ; 5,5 ; 6,5$ e 7,5 $\mathrm{dS} \mathrm{m}{ }^{-1}$ e quatro temperaturas de $25,30,35$ e $20-30^{\circ} \mathrm{C}$, em quatro repetições de 25 sementes cada. Os efeitos da salinidade e da temperatura foram avaliados por meio da germinação, índice de velocidade de germinação, comprimento da parte aérea e da raiz, massa seca da parte aérea e da raiz e total de plântulas. O aumento dos níveis de salinidade da água interfere em todas as variáveis analisadas na germinação de sementes de $S$. gardneriana, principalmente sob a temperatura de $35^{\circ} \mathrm{C}$. Nas temperaturas de $25 \mathrm{e}$ $30{ }^{\circ} \mathrm{C}$ a germinação e o desenvolvimento inicial das sementes são menos afetados pela salinidade. As sementes de $S$. gardneriana são sensíveis à salinidade causada pelo aumento do $\mathrm{NaCl}$ a partir de 1,5 $\mathrm{dS} \mathrm{m}{ }^{-1}$, o que indica baixa tolerância desta espécie em ambientes salinos. Os resultados obtidos neste trabalho mostram que o efeito negativo na germinação e desenvolvimento inicial de plântulas de $S$. gardneriana pode ser explicado pelo aumento dos níveis salinos e temperatura, reduzindo o poder da planta em absorver água e nutrientes, o que indica respostas de sensibilidade dessa espécie a salinidade e ao estresse térmico.

Palavras-chave: Bioma Caatinga. Condutividade elétrica. Estresse salino. Estresse térmico. Vigor.

\section{Introduction}

Simira gardneriana M.R. Barbosa \& Peixoto (Rubiaceae) is a shrub species, popularly known in Portuguese as 'pereiro-vermelho' or 'pereirode-tinta', reaching 4-7 $\mathrm{m}$ in height, and exclusively found in the Caatinga of the central region of Northeast Brazil. During the drought period, its leaves are used as forage feed for cattle and its wood as firewood and posts in the construction of fences (BARBOSA; PEIXOTO, 2000; LORENZI, 2009).

Regarding the species of the Caatinga biome, such as $S$. gardneriana, studies involving germination under salt and thermal stress conditions are justified because the chances of survival in this environment, with a hot and dry climate, are limited due to the adverse conditions typical of this region.

Thus, studying the initial phase of germination helps understand the germinative response of the seeds to salt stress (CHAVES et al., 2013), and the reduction in germination capacity, compared to the control, is an indication of the salinity tolerance index of the species (LIMA; TORRES, 2009).

Several studies have been conducted to assess salinity effects on germination and initial development of seedlings in species of the Caatinga, including Chorisia glaziovii (GUEDES et al., 2011), Capparis flexuosa (PACHECO et al., 2012), Parkinsonia aculeata (BEZERRA et al., 2013), Erythrina vellutina (GUIMARÃES et al., 2013), Myracrodruon urundeuva e Bauhinia cheilantha (OLIVEIRA et al., 2014), Tabebuia caraiba (SILVA et al., 2014), Albizia lebbeck (LIMA et al., 2015), and Piptadenia moniliformis (PEREIRA et al., 2016). All these studies found that irrigation water salinity had negative effects on the germination and initial development of these species.

Besides water or substrate salinity, another important factor, which must be evaluated during seed germination, is temperature, because it affects germination rate, speed, and uniformity (MARCOSFILHO, 2015). Optimal temperatures allow the most efficient combination of these variables (CARVALHO; NAKAGAWA, 2012).

Due to the importance of this species and the lack of data in the literature about its response to salinity and thermal stress, we assessed the effect of four temperatures and eight levels of $\mathrm{NaCl}$-induced salinity on the germination and initial development of $S$. gardneriana seedlings. 


\section{Material and Methods}

The experiment was conducted at the Seed Analysis Laboratory of the Center of Agrarian Sciences of the Federal Rural University of the Semi-Arid Region, Mossoró, RN, Brazil, using $S$. gardneriana seeds collected in the municipality of Afrânio, PE, Brazil ( $8^{\circ} 30^{\prime} 42^{\prime \prime} \mathrm{S}, 41^{\circ} 00^{\prime} 36^{\prime \prime} \mathrm{W}$ and $540 \mathrm{~m}$ above sea level), obtained from the Caatinga Reference Center for Recovery of Degraded Areas of the Federal University of São Francisco Valley (CRAD/UNIVASF), Petrolina, PE, Brazil. Seeds remained in Kraft paper bags, stored in a cold chamber $\left(10^{\circ} \mathrm{C}\right.$ and $50 \%$ relative humidity $)$ prior to the experiment.

We used seeds with an initial moisture content of $12.32 \%$, which were subjected to varying levels of salinity and to different temperatures. The solutions with different levels of salinity were obtained by adding sodium chloride $(\mathrm{NaCl})$ to distilled water at the following concentrations: 0.0 (control), 1.5 , $2.5,3.5,4.5,5.5,6.5$, and $7.5 \mathrm{dS} \mathrm{m}^{-1}$. Electrical conductivity values were measured using a digital conductivity meter, Tec-4MP model, Tecnal ${ }^{\circledR}$ brand. After preparing the solutions, seeds were distributed

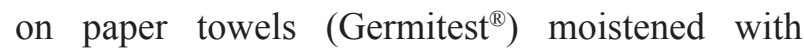
distilled water (control) or saline solution, using a volume equivalent to 2.5 times the mass of the dry paper, and placed in a Biochemical Oxygen Demand (B.O.D.) germinator, Bunker ${ }^{\circledR}$ brand, at constant temperatures of 25,30 , and $35^{\circ} \mathrm{C}$ and alternating temperatures of $20-30^{\circ} \mathrm{C}$, under an 8 -h photoperiod. To assess the effects of salinity and temperature, the following evaluations were carried out:

a) Germination - final germination percentage was evaluated at 30 days after sowing, considering as germinated the seeds with primary root length equal to or greater than $2 \mathrm{~mm}$.

b) Germination speed index - determined within the germination test by daily counting the seedlings from the $6^{\text {th }}$ to the $20^{\text {th }}$ day after sowing, calculated as recommended by Maguire (1962).

c) Seedling shoot and root lengths - at the end of the germination test, all normal seedlings of each treatment were measured using a graduated ruler for shoot length, measuring from the collar base to the point of attachment of the cotyledon leaves, and root length from the collar base to the tip of the main root. The obtained data were expressed in centimeters per seedling.

d) Seedling shoot, root and total dry matter - shoots and roots of normal seedlings of each replicate were separated using scissors, placed in paper bags, and dried in a forced air circulation oven at $65^{\circ} \mathrm{C}$ until constant weight (72 hours). After this period, the samples were weighed on an analytical scale $(0.001 \mathrm{~g})$, and the average results were expressed in $\mathrm{g}$ seedling ${ }^{-1}$. Total dry matter was calculated by summing the values of shoot and root dry matter.

The experimental design was completely randomized, with treatments distributed in an $8 \mathrm{x}$ 4 factorial scheme (salinity levels $\mathrm{x}$ temperatures), in four replicates of 25 seeds each, totaling 128 experimental units. The results were subjected to analysis of variance by the $\mathrm{F}$ test at 0.05 probability level and, in cases of significance, regression analysis was carried out, and the models were selected based on the coefficients of determination and their significance. The analyses were carried out using the statistical software SISVAR $^{\circledR}$ (FERREIRA, 2011).

\section{Results and Discussion}

Table 1 presents the results of the analysis of variance for $S$. gardneriana seeds under different salinity levels and temperatures.

Based on Table 1, the levels of irrigation water salinity and the different temperatures influenced germination percentage, shoot length, root length, and root dry matter. Germination speed index, shoot dry matter, and total dry matter were individually affected by the studied factors, which indicates that the different temperatures had similar effects at the different levels of irrigation water salinity. 
Table 1. Results of the analysis of variance for Simira gardneriana seeds subjected to different levels of irrigation water salinity (SL) and temperatures (T).

\begin{tabular}{lcccccccc}
\hline \multirow{2}{*}{$\mathrm{SV}$} & DF & \multicolumn{7}{c}{ F values } \\
\cline { 3 - 8 } & & $\mathrm{G}(\%)$ & GSI & SL $(\mathrm{cm})$ & RL $(\mathrm{cm})$ & SDM $(\mathrm{g})$ & RDM $(\mathrm{g})$ & $\mathrm{TDM}(\mathrm{g})$ \\
\hline $\mathrm{SL}$ & 7 & $4.77^{* *}$ & $28.65^{* *}$ & $133.66^{* *}$ & $19.90^{* *}$ & $24.82^{* *}$ & $15.49^{* *}$ & $27.86^{* *}$ \\
$\mathrm{~T}$ & 3 & $69.53^{* *}$ & $387.27^{* *}$ & $607.99^{* *}$ & $298.95^{* *}$ & $335.55^{* *}$ & $444.45^{* *}$ & $476.08^{* *}$ \\
SL x T & 21 & $2.73^{* *}$ & $1.24^{\text {ns }}$ & $10.93^{* *}$ & $8.03^{* *}$ & $1.13^{\text {ns }}$ & $2.46^{* *}$ & $1.59^{\text {ns }}$ \\
Mean & - & 86.55 & 1.50 & 1.79 & 5.66 & 0.36 & 0.15 & 0.51 \\
\hline CV $(\%)$ & - & 7.17 & 8.49 & 10.83 & 14.39 & 16.29 & 17.68 & 14.61 \\
\hline
\end{tabular}

$\mathrm{SL}=$ Salinity level; $\mathrm{T}=$ Temperature; $\mathrm{SV}=$ Sources of variation; $\mathrm{CV}=$ Coefficient of variation; $\mathrm{DF}=\mathrm{Degrees}$ of freedom; $\mathrm{G}=$ Germination; GSI = Germination speed index; SL = Shoot length; RL = Root length; SDM = Shoot dry matter; RDM = Root dry matter; TDM $=$ Total dry matter. ${ }^{* *}=$ Significant by F test $(\mathrm{p}<0.01) ;{ }^{\text {ns }}=$ Not significant by $\mathrm{F}$ test.

The germination of $S$. gardneriana seeds, under the different salt and thermal stresses, was affected by the increase in irrigation water salinity. However, seeds germinated at a temperature of $25^{\circ} \mathrm{C}$ obtained stable germination percentages at all levels tested
(Figure 1A). This response is an indication that this temperature is optimal for this species, since the seeds were able to express their germination potential even under unfavorable conditions (FANTI; PEREZ, 1996).

Figure 1. Germination (A), germination speed index (GSI) (B), shoot length (SL) (C), and root length (RL) (D) of Simira gardneriana seedlings subjected to different levels of irrigation water salinity and temperatures.

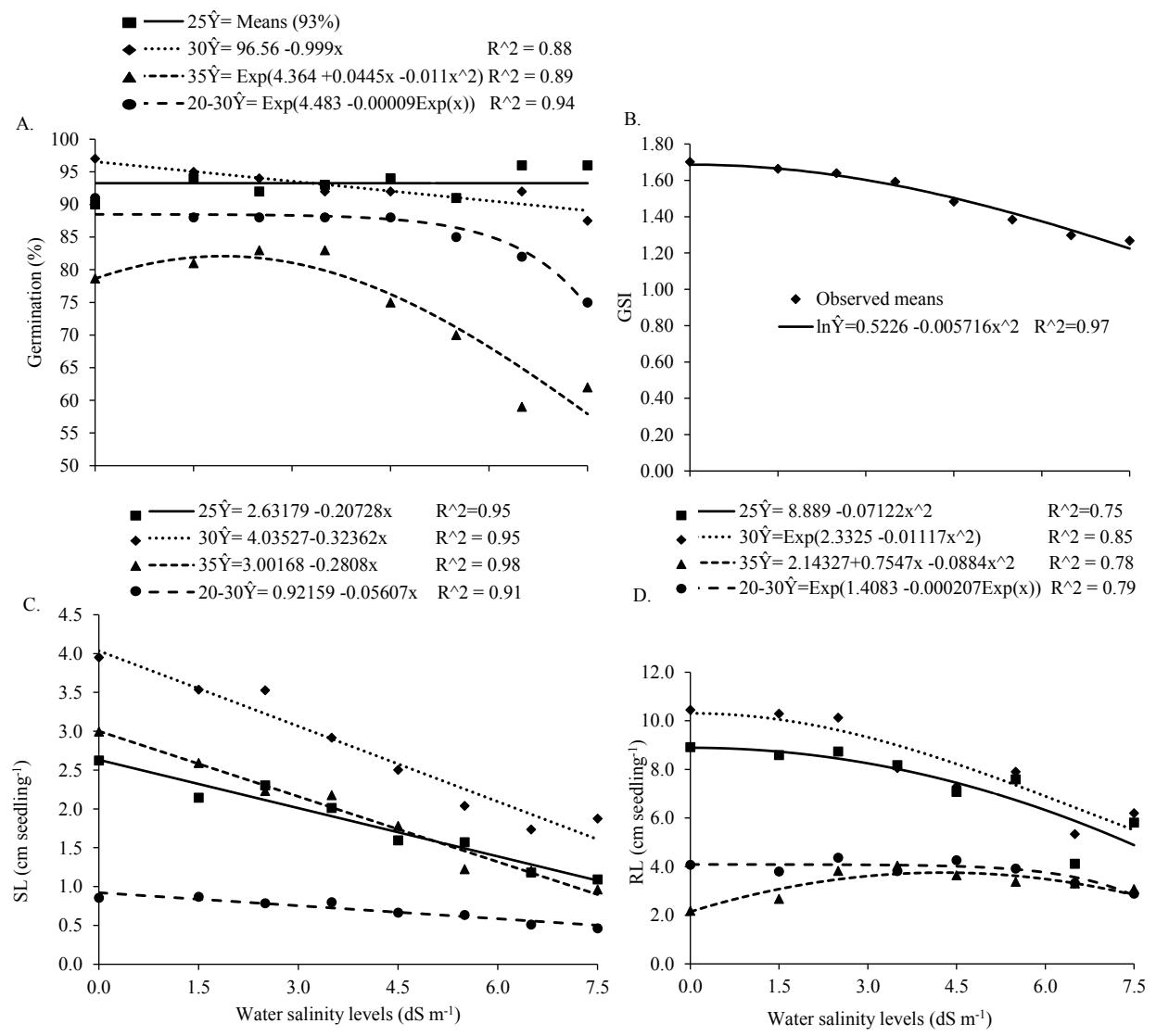


For the temperatures of 30 and $20-30^{\circ} \mathrm{C}$, highest germination percentages were obtained when seeds were placed in substrate moistened with distilled water $\left(0.0 \mathrm{dS} \mathrm{m}^{-1}\right)$, reaching 97 and $91 \%$, respectively. From this level, germination remained virtually stable up to $4.5 \mathrm{dS} \mathrm{m}^{-1}$, reaching $90 \%\left(30^{\circ} \mathrm{C}\right)$ and $75 \%\left(20-30^{\circ} \mathrm{C}\right)$ at an electrical conductivity of $7.5 \mathrm{dS} \mathrm{m}^{-1}$.

On the other hand, germination percentage increased up to $3.5 \mathrm{dS} \mathrm{m}^{-1}$ when seeds were placed to germinate at a temperature of $35^{\circ} \mathrm{C}$, with a significant decrease from this level. This temperature was also responsible for the lowest germination percentages at all salinity levels tested, evidencing that it should not be used to conduct germination tests with $S$. gardneriana seeds as it possibly accelerates seed respiration and deterioration (GUEDES et al., 2011). Harmful effects of salt stress on seed germination at a temperature of $35^{\circ} \mathrm{C}$ have also been observed for Peltophorum dubium (ALVES et al., 2011), Chorisia glaziovii (GUEDES et al., 2011), and Piptadenia moniliformis (PEREIRA et al., 2016).

Some studies have demonstrated negative effects of irrigation water salinity on the germination of forest species from the Caatinga, such as Tabebuia caraiba, for which germination performance decreased significantly from $2.5 \mathrm{dS} \mathrm{m}^{-1}$ (SILVA et al., 2014). Chorisia glaziovii seeds showed lower germination percentages with an increasing salinity, reaching percentages of 38,14 , and $35 \%$ at $6.0 \mathrm{dS} \mathrm{m}^{-1}$ when subjected to temperatures of 25,30 , and $20-30^{\circ} \mathrm{C}$, respectively (GUEDES et al., 2011). By contrast, Capparis flexuosa seeds were highly resistant to salt stress, germinating under high concentrations of sodium chloride, which is characteristic for halophytes (PACHECO et al., 2012).

Germination speed index data fitted to a quadratic model for the levels of salinity, regardless of the temperature tested, and decreased by $25 \%$ from the lowest to the highest level of water electrical conductivity (Figure 1B).

In relation to the different temperatures (Table 2), seeds that germinated at 25 and $30^{\circ} \mathrm{C}$ obtained higher indices, not differing statistically from one another, but differing from the temperatures of 20 30 and $35^{\circ} \mathrm{C}$, the latter of which being responsible for the lowest means. Carvalho and Nakagawa (2012) claim that temperatures below or above optimal tend to reduce germination because seeds remain exposed to the adverse effects of the stress conditions for a longer time.

Table 2. Means of germination speed index (GSI), shoot dry matter (SDM), and total dry matter (TDM) of Simira gardneriana seedlings subjected to different levels of irrigation water salinity and temperatures.

\begin{tabular}{cccc}
\hline \multirow{2}{*}{ Temperatures $\left({ }^{\circ} \mathrm{C}\right)$} & GSI & SDM & TDM \\
\cline { 3 - 4 } & & \multicolumn{2}{c}{ g seedling $^{-1}$} \\
\hline 25 & $1.86 \mathrm{a}^{*}$ & $0.51 \mathrm{a}$ & $0.73 \mathrm{a}$ \\
30 & $1.91 \mathrm{a}$ & $0.54 \mathrm{a}$ & $0.78 \mathrm{a}$ \\
$20-30$ & $1.03 \mathrm{c}$ & $0.17 \mathrm{c}$ & $0.20 \mathrm{c}$ \\
\hline
\end{tabular}

*Means followed by the same lowercase letter in the column do not differ by Tukey's test at 0.05 probability level.

According to Gordin et al. (2012), water availability is a limiting factor during the initial phases of seedling establishment, resulting in a reduction of germination speed, especially in species whose mechanisms of tolerance to salt stress are absent or inefficient during the initial phases of 
germination. Reductions in germination speed index have also been observed in seeds of Myracroduon urundeuva (OLIVEIRA et al., 2007), Mimosa caesalpiniifolia (RIBEIRO et al., 2008; BARRETO et al., 2010), Guazuma ulmifolia (BETONI et al., 2011), Cedrela odorata (FERREIRA et al., 2013), Dimorphandra mollis (MASETTO et al., 2014), Alibertia edulis (NUNES et al., 2014), and Myracrodruon urundeuva and Bauhinia cheilantha (OLIVEIRA et al., 2014).

Regarding the effects of salinity levels on shoot length, there was a linear reduction in the dimensions of $S$. gardneriana seedlings at all temperatures used (Figure 1C). Highest values of shoot length occurred at $0.0 \mathrm{dS} \mathrm{m}{ }^{-1}\left(2.63 \mathrm{~cm}-25^{\circ} \mathrm{C} ; 3.95 \mathrm{~cm}-30^{\circ} \mathrm{C} ; 2.99\right.$ $\mathrm{cm}-35^{\circ} \mathrm{C} ; 0.86 \mathrm{~cm}-20-30^{\circ} \mathrm{C}$ ). At a temperature of $25^{\circ} \mathrm{C}$, seedling length decreased from the level of $0.0 \mathrm{dS} \mathrm{m}^{-1}$ to $1.5 \mathrm{dS} \mathrm{m}^{-1}$, with a subsequent increase up to $2.5 \mathrm{dS} \mathrm{m}^{-1}$, followed by a reduction, reaching $1.09 \mathrm{~cm}^{2} 7.5 \mathrm{dS} \mathrm{m}^{-1}$.

At $30^{\circ} \mathrm{C}$, seedling length was more affected by the increase in salinity levels than at the other temperatures. For seedlings grown from seeds subjected to a temperature of $35^{\circ} \mathrm{C}$, seedling length decreased by $68 \%$ between the treatments of lowest and highest salinity levels. At the temperature of 20$30^{\circ} \mathrm{C}$, there was an increase in seedling length from the level of 1.5 to $2.5 \mathrm{dS} \mathrm{m}^{-1}$; however, from this level on, there were reductions in seedling length, leading to considerably inferior results compared to the other temperatures at all salinity levels.

Likewise, Ferreira et al. (2013) and Nunes et al. (2014) observed that shoot length in Cedrela odorata and Alibertia edulis, respectively, was affected by the increase in salt concentrations. Lima et al. (2015) also found a reduction of shoot length in Albizia lebbeck seedlings with increasing irrigation water salinity, and the maximum estimated value of 7.42 $\mathrm{cm}$ was obtained at a salinity of $0.68 \mathrm{dS} \mathrm{m}^{-1}$, which led to a loss of $83 \%$ between the concentrations of 0.68 and $4.5 \mathrm{dS} \mathrm{m}^{-1}$.

Reduction in seedling length can be justified by the osmotic effect of substrate salinity, affecting water absorption by roots, or by the specific effect or excess of the ions which enter the transpiration flux, eventually causing leaf injury, reduced growth, or negatively influencing the absorption of essential elements (MUNNS, 2005).

Main root length was also affected by the different levels of water salinity and temperature (Figure 1D). Seedlings subjected to temperatures of 25 and $30^{\circ} \mathrm{C}$ were less harmed by salinity, showing higher values in the substrate moistened with distilled water $\left(0.0 \mathrm{dS} \mathrm{m}^{-1}\right)$, with 8.92 and $10.45 \mathrm{~cm}$, respectively. Similar observations were made by Pereira et al. (2016) in seeds of Piptadenia moniliformis and by Guedes et al. (2011) in seeds of Chorisia glaziovii.

Plants subjected to high salt stress showed reduced root permeability to water, consequently closing the stomata and delaying plant development, with more severe effects on glycophyte species (TAIZ; ZEIGER, 2013). Thus, given this information, $S$. gardneriana seedlings are suggested to be sensitive to irrigation water salinity. Several authors, studying salinity effects on seedling growth and initial development (GUEDES et al., 2011; FERREIRA et al., 2013; GUIMARÃES et al., 2013; NUNES et al., 2014; LIMA et al., 2015), have reported that the increase in salinity levels led to negative effects on root length, as found in the present study.

According to Figure 2A, there was no significant interaction between temperatures and levels of water salinity for shoot dry matter, demonstrating that the reduction in dry matter accumulation with the increase of salinity occurred equally at the four temperatures used. 
Figure 2. Shoot dry matter (SDM) (A), root dry matter (RDM) (B), and total dry matter (TDM) (C) of Simira gardneriana seedlings subjected to different levels of irrigation water salinity and temperatures.

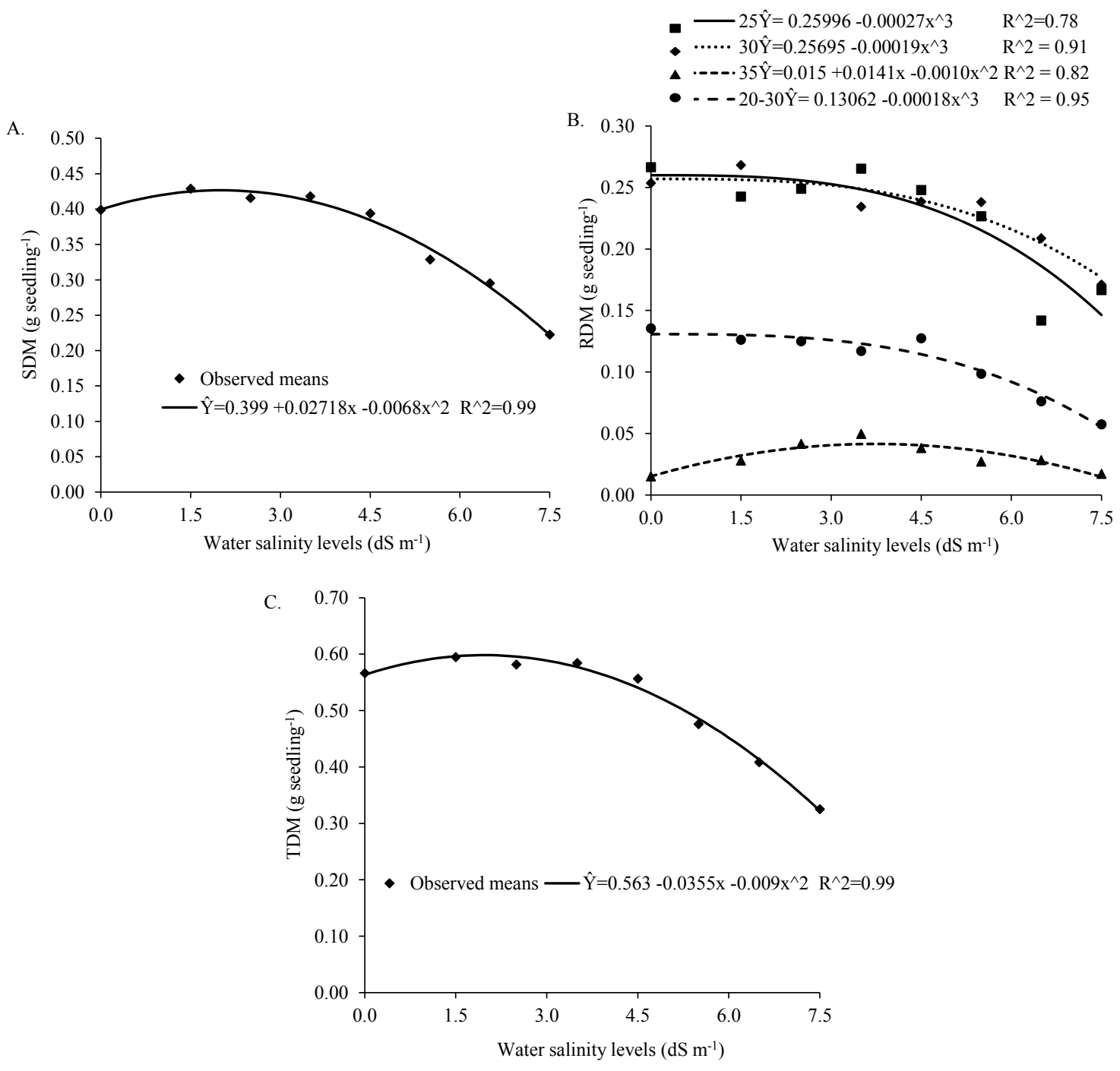

According to the equation, shoot dry matter remained virtually stable up to the salinity level of $4.5 \mathrm{dS} \mathrm{m}^{-1}$. From this conductivity level onward, it decreased by $45 \%$ compared to the percentage difference between the lowest and highest levels of irrigation water salinity, showing that the increase in water salinity directly influences shoot dry matter of $S$. gardneriana seedlings. In relation to the temperatures, the shoot dry matter of seedlings subjected to temperatures of 25 and $30^{\circ} \mathrm{C}$ led to higher dry matter accumulation, statistically differing from the temperature of $20-30^{\circ} \mathrm{C}$, which in turn differed from $35^{\circ} \mathrm{C}$ (Table 2).

Likewise, Nogueira et al. (2012), studying the effects of different salt concentrations in the irrigation water on the emergence and initial development of flamboyant (Delonix regia) seedlings, observed highest and lowest values of shoot dry matter at 0.5 and $6.0 \mathrm{dS} \mathrm{m}^{-1}$, respectively. Similar results were also obtained by Nunes et al. (2014), who observed a reduction in the shoot dry matter of 'marmelo' (Alibertia edulis) seedlings with increasing salt concentrations. 
The shoot dry matter of $S$. gardneriana seedlings was efficient at indicating the negative effects of both irrigation water salinity levels and temperatures, since the increase in electrical conductivity led to a reduction in root mass (Figure 2B). Similar to what occurred in the previously discussed variables, temperatures of 25 and $30^{\circ} \mathrm{C}$ were less harmful to root dry matter, regardless of the salinity levels tested. For seedlings grown from seeds subjected to temperatures of $20-30^{\circ} \mathrm{C}$, root dry matter accumulation reached $0.13 \mathrm{~g}$ in the treatment with distilled water and $0.06 \mathrm{~g}$ at the highest level of salinity $\left(7.5 \mathrm{dS} \mathrm{m}^{-1}\right)$. Among all temperatures evaluated, the temperature of $35^{\circ} \mathrm{C}$ led to the lowest root dry matter and is therefore not suitable for seedling development.

The total dry matter of $S$. gardneriana seedlings showed a similar response compared to that of shoot dry matter and germination speed index, in which the data fitted to a quadratic model for the salinity levels, regardless of the temperature. Increasing irrigation water salinity led to a reduction of about $42 \%$ in total dry matter between the control treatment and the highest level of salinity (Figure 2C). In terms of temperature, $30^{\circ} \mathrm{C}$ led to highest means of total dry matter, similar to a temperature of $25^{\circ} \mathrm{C}$, which in turn differed from the others; the temperature of $35^{\circ} \mathrm{C}$ resulted in the lowest values of total dry matter accumulation (Table 2).

\section{Conclusions}

The results obtained in the present study show that the negative effect on the germination and initial development of $S$. gardneriana seedlings can be explained by the increase in salinity levels and temperature, reducing the capacity of the plant to absorb water and nutrients, which indicates sensitivity responses of this species to salinity and thermal stress.

Increasing levels of water salinity interfere with the germination of $S$. gardneriana seeds, especially at a temperature of $35^{\circ} \mathrm{C}$.
Germination and initial development of $S$. gardneriana seedlings are less affected by salinity at temperatures of 25 and $30^{\circ} \mathrm{C}$.

The seeds of $S$. gardneriana are sensitive to salinity caused by the increase of $\mathrm{NaCl}$ from $1.5 \mathrm{dS}$ $\mathrm{m}^{-1}$, which indicates a low tolerance of this species to saline environments.

\section{Acknowledgements}

The authors thank Dr José Alves de Siqueira Filho, head of the Caatinga Reference Center for Recovery of Degraded Areas of the Federal University of São Francisco Valley (CRAD/ UNIVASF), for providing the seeds.

\section{References}

ALVES, E. U.; GUEDES, R. S.; GONÇALVES, E. P.; VIANA, J. S.; SANTOS, S. S.; MOURA, M. F. Effect of temperature and substrate on germination of Peltophorum dubium (Sprengel) Taubert seeds. Acta Scientiarum. Biological Sciences, Maringá, v. 33, n. 1, p. 113-118, 2011. DOI:10.4025/actascibiolsci.v33i1.7057

BARBOSA, M. R. V.; PEIXOTO, A. L. A new species of Simira (Rubiaceae, Rondeletieae) from Northeastern Brazil. Novon, Saint Louis, v. 10, n. 1, p. 110-112, 2000. DOI: $10.2307 / 3393006$

BARRETO, H. B. F.; FREITAS, R. M. O.; OLIVEIRA, L. A. A.; ARAUJO, J. A. M.; COSTA, E. M. Efeito da irrigação com água salina na germinação de sementes de sábia (Mimosa caesalpiniifolia Benth.). Revista Verde de Agroecologia e Desenvolvimento Sustentável, Mossoró, v. 5, n. 3, p. 125-130, 2010.

BETONI, R.; SCALON, S. P. Q.; MUSSURY, R. M. Salinidade e temperatura na germinação e vigor de sementes de mutambo (Guazuma ulmifolia Lam.) (Sterculiaceae). Revista Árvore, Viçosa, MG, v. 35, n. 3, p. 605-616, 2011.

BEZERRA, F. T. C.; ANDRADE, L. A.; CAVALCANTE, L. F.; PEREIRA, W. E.; BEZERRA, M. A. F. Emergência e crescimento inicial de plantas de Parkinsonia aculeata L. (Fabaceae) em substrato salino. Revista Árvore, Viçosa, MG, v. 37, n. 4, p. 611-618, 2013.

CARVALHO, N. M.; NAKAGAWA, J. Sementes: ciência, tecnologia e produção. 5. ed. Jaboticabal: FUNEP, 2012. $590 \mathrm{p}$. 
CHAVES, A. P.; LIMA, J. S. S.; RIBEIRO, M. C.; BENEDITO, C. P.; RODRIGUES, S. O. Efeito da salinidade na emergência e desenvolvimento de plântulas de flamboyant. Revista Agropecuária Científica no Semiárido, Patos, v. 9, n. 3, p. 119-123, 2013. DOI: 10.30969/acsa.v9i3.312

FANTI, S. C.; PEREZ, S. C. J. G. A. Efeitos do estresse hídrico e salino na germinação de Bauhinia forficata Link. Revista Ceres, Viçosa, MG, v. 43, n. 249, p. 654662, 1996.

FERREIRA, D. F. Sisvar: a computer statistical analysis system. Ciência e Agrotecnologia, Lavras, v. 35 , n. 1, p. 1039-1042, 2011. DOI: 10.1590/S141370542011000600001

FERREIRA, E. G. B. S.; MATOS, V. P.; SENA, L. H. M.; OlIVEIRA, R. G.; SALES, A. G. F. A. Processo germinativo e vigor de sementes de Cedrela odorata $\mathrm{L}$. sob estresse salino. Ciência Florestal, Santa Maria, v. 23, n. 1, p. 99-105, 2013.

GORDIN, C. R. B.; MARQUES, R. F.; MASETTO, T. E.; SOUZA, L. C. F. Estresse salino na germinação de sementes e desenvolvimento de plântulas de niger (Guizotia abyssinica (L. f.) Cass.). Acta Botanica Brasilica, Feira de Santana, v. 26, n. 4, p. 966-972, 2012. DOI: $10.1590 / \mathrm{S} 0102-33062012000400026$

GUEDES, R. S.; ALVES, E. U.; GALINDO, E. A.; BARROZO, L. M. Estresse salino e temperaturas na germinação e vigor de sementes de Chorisia glaziovii $\mathrm{O}$. Kuntze. Revista Brasileira de Sementes, Londrina, v. 33, n. 2, p. 279-288, 2011.

GUIMARÃES, I. P.; OLIVEIRA, F. N.; VIEIRA, F. E. R.; TORRES, S. B. Efeito da salinidade da água de irrigação na emergência e crescimento inicial de plântulas de mulungu. Revista Brasileira de Ciências Agrárias, Recife, v. 8, n. 1, p. 137-142, 2013. DOI:10.5039/agraria. v8i1a2360

LIMA, B. G.; TORRES, S. B. Estresses hídrico e salino na germinação de sementes de Zizyphus joazeiro Mart. (Rhamnaceae). Revista Caatinga, Mossoró, v. 22, n. 1, p. 93-99, 2009.

LIMA, M. F. P.; PORTO, M. A.; TORRES, S. B.; FREITAS, R. M. O.; NOGUEIRA, N. W.; CARVALHO, D. R. Emergência e crescimento inicial de plântulas de albízia submetidas à irrigação com água salina. Revista Brasileira de Engenharia Agrícola e Ambiental, Campina Grande, v. 19, n. 2, p. 106-112, 2015. DOI: 10.1590/1807-1929/agriambi.v19n2p106-112

LORENZI, H. Árvores brasileiras: manual de identificação e cultivo de plantas arbóreas nativas do
Brasil. Nova Odessa: Instituto Plantarum, 2009. v. 2, 384 p.

MAGUIRE, J. D. Speed of germination aid in selection and evaluation for seedling and vigour. Crop Science, Madison, v. 2, n. 1, p. 176-177, 1962.

MARCOS-FILHO, J. Fisiologia de sementes de plantas cultivadas. Londrina: ABRATES, 2015. 659 p.

MASETTO, T. E.; SCALON, S. P. Q.; REZENDE, R. K. S.; OBA, G. C.; GAMBATTI, M.; PATRÍCIO, V. S. Germinação de sementes de Dimorphandra mollis Benth.: efeito de salinidade e condicionamento osmótico. Revista Brasileira de Biociências, Porto Alegre, v. 12, n. 3, p. 127-131, 2014.

MUNNS, R. Genes and salt tolerance: bringing them together. New Phytologist, Cambridge, v. 167, n. 3, p. 645-663, 2005. DOI:10.1111/j.1469-8137.2005.01487.x

NOGUEIRA, N. W.; LIMA, J. S. S.; FREITAS, R. M. O.; RIBEIRO, M. C. A.; LEAL, C. C. P.; PINTO, J. R. $\mathrm{S}$. Efeito da salinidade na emergência e crescimento inicial de plântulas de flamboyant. Revista Brasileira de Sementes, Londrina, v. 34, n. 1, p. 466-472, 2012.

NUNES, D. P.; SCALAN, S. P. Q.; BONAMIGO, T.; MUSSURY, R. S. Germinação de sementes de marmelo: temperatura, luz e salinidade. Bioscience Journal, Uberlândia, v. 30, n. 6, p. 1737-1745, 2014.

OLIVEIRA, A. M.; LINHARES, P. C. F.; MARACAJÁ, P. B.; RIBEIRO, M. C. C.; BANEDITO, C. C. Salinidade na germinação e desenvolvimento de plântulas de aroeira (Myracroduon urundeuva Fr All). Revista Caatinga, Mossoró, v. 20, n. 2, p. 39-42, 2007.

OLIVEIRA, G. M.; MATIAS, J. R.; SILVA, P. P.; RIBEIRO, R. C.; DANTAS, B. F. Germinação de sementes de aroeira-do-sertão (Myracrodruon urundeuva Fr. All.) e mororó (Bauhinia cheilantha (Bong) Stend.) em diferentes condutividades elétricas. Revista Sodebras, São Paulo, v. 9, n. 104, p. 70-73, 2014.

PACHECO, M. V.; FERRARI, C. S.; BRUNO, R. L. A.; ARAÚJO, F. S.; SILVA, G. Z.; ARRUDA, A. A. Germinação e vigor de sementes de Capparis flexuosa L. submetidas ao estresse salino. Revista Brasileira de Ciências Agrárias, Recife, v. 7, n. 2, p. 301-305, 2012. DOI: 10.5039 /AGRARIA.V7I2A1314

PEREIRA, F. E. C. B.; MEDEIROS FILHO, S.; TORRES, S. B.; MARTINS, C. C.; BRITO, S. F. Saline stress and temperatures on germination and vigor of Piptadenia moniliformis Benth. seeds. Revista Brasileira de Engenharia Agrícola e Ambiental, Campina Grande, v. 20 , n. 7 , p. $649-653$, 2016. DOI: 10.1590/1807-1929/ agriambi.v20n7p649-653 
RIBEIRO, M. C. C.; BARROS, N. M. S.; BARROS JÚNIOR, A. P.; SILVEIRA, L. M. Tolerância do sabiá (Mimosa caesalpiniifolia Benth.) à salinidade durante a germinação e o desenvolvimento de plântulas. Revista Caatinga, Mossoró, v. 21, n. 5, p. 123-126, 2008.
SILVA, T. T. S.; LIMA, V. L. A.; ALVES, A. R. S.; MONTEIRO, D. R. M.; FERREIRA FILHO, J. G. A. Estresse salino na germinação de sementes de craibeira. Revista Educação Agrícola Superior, Brasília, v. 29, n. 1, p. 23-25, 2014.

TAIZ, L.; ZEIGER, E. Fisiologia vegetal. 5. ed. Porto Alegre: Artmed, 2013. 918 p. 